\title{
SEKA Kağıt Fabrikası Endüstriyel Mirasın Dijital Yöntemlerle Aktarılması
}

\section{Digital Representation of SEKA Paper Mill's Industrial Heritage}

\author{
D Üftade Muşkara, (D) Oylum Tunçelli \\ Kocaeli Üniversitesi, Güzel Sanatlar Fakültesi Kültür Varlıklarını Koruma ve Onarım Bölümü, Fotoğraf Bölümü, Kocaeli
}

\section{ÖZ}

Günümüzde endüstriyel arkeoloji ve endüstriyel miras kavramları konusunda yapılan akademik çalışmaların sayısı artmaktadır. Bunun bir nedeni kültürel mirasa konu olan araştırmaların akademik çatısının genişlemesi ve farklı uzmanlık alanlarının konuya dahil olmasıdır. Nizhny Tagil Tüzüğü (2003) ile endüstriyel miras "Tarihsel, teknolojik, sosyolojik, mimari ya da bilimsel değeri olan endüstriyel kültürün maddi kalıntıları" olarak tanımlanmaktadır. Fakat, endüstriyel miras aynı zamanda somut olmayan kültürel miras formunu da taşımaktadır. Bu durumun ülkemizdeki yansımalarını özellikle ilk sanayileşme dönemi ile ilişkilendirebiliriz. Türkiye Cumhuriyeti'nin endüstriyel gelişiminin ürünleri olan fabrikalar, aynı zamanda ülkedeki büyük sosyal ve kültürel değişimin göstergeleri olarak da önem kazanmaktadır. Fabrika ve yerleşkelerindeki sosyal hayat, değişiminin yerel ölçekte temsilidir. Bu nedenle terk edilmiş endüstriyel alanların korunması ve yeniden işlevlendirilmesi, endüstriyel alanın tüm katmanlarını yansıtacak şekilde bütüncül yaklaşımları gerektirmektedir. Araştırma dijital yöntemlerin, endüstriyel miras alanında kullanıcı/ziyaretçi ve kentteki paydaşlara aktarılmasındaki kullanılabilirliğini SEKA Kağıt Müzesi kapsamında değerlendirmektedir.

Anahtar sözcükler: Arttırılmış gerçeklik; dijital görüntü; endüstriyel miras; SEKA Kağıt Müzesi; sergileme.

\begin{abstract}
Industrial heritage today is being taken even more seriously by academes. It is due to the instituting of heritage studies across humanities, social sciences and natural sciences and developments in contemporary archaeology. Industrial heritage is broadly defined by many specialists after Nizhny Tagil Charter (2003) as consisting of "the remains of industrial culture which are of historical, technological, social, architectural or scientific value". Meantime, industrial heritage comprises more then just material culture, but also valuable intangible forms of heritage. In the case of factories as the products of early industrial developments in Turkish Republic during 20's and 50's, they provide us important insights about the structural alteration in culture and social life in the region. Lives in factories and their campus areas were the representation of transforming identities of young republic. Therefore, preserving and conserving of such sites should consider not just the building itself but tangible and intangible heritages values together. Temporal layers including the time when the factory was still active, when it was abandoned and spatial layers including living and working quarters of industrial sites should be equally transmitted to various targets groups. This project considers how digital visualization contributes to perception of visitors with maintaining cultural mediation in SEKA Paper Museum situated former pulp and paper mill in Kocaeli district.

Keywords: augmented reality; digital visualization; industrail heritage; SEKA Paper Museum; exhibition.
\end{abstract}




\section{Giriş}

Avrupa'da 18. yüzyılda sanayi devrimi birlikte başlayan üretim dönemi, ülkelerin hem ekonomik hem sosyal hayatlarında büyük bir değişime neden olmuştur. Toplum, sanayi üretiminin yapıldığı alanlara göç etmeye başlamış ve insanlık tarihinde ilk defa kentsel nüfus kırsal alan nüfusundan daha fazla olmuştur. Böylelikle birey-bölge aidiyeti kırılmıştır. Ancak sanayileşmenin getirdiği ekonomik gücü ve zenginliği o dönemde üretimin diğer alanları ile karşılaştırmak zordur. Bu gücün devamlılı̆̆, kapitalist sistem üzerine tüketim toplumunun gelişmesiyle sağlanmıştır. İkinci Dünya Savaşı sonrasında, özellikle 1970’li yıllarda kapitalizmin tekrar keşfi ile gelişmiş ülkeler olarak tanımlanan coğrafyada üretime dayalı düzen yerini hizmet temelli ekonomi ve bilişim teknolojileri ekonomisine bırakmıştır. Yaklaşık iki yüzyıl devam eden sanayi üretimine bağlı yaşam biçimleri, sosyal tabakalar ve mekânsal yaklaşımlar terk edilmiştir.

Avrupa ile karşılaştırdığımızda, sanayileşme süreci ve etkilileri Türkiye'de farklı dinamiklerin etkisi ile şekillenmiştir. Cumhuriyet'in ilk yıllarında, “iktisadi Toparlanma Devri” adı verilen 1923-1932 arası dönemde, ülkenin savaşlar sonrası ekonomik durumunun sanayi üretimle güçlendirilmesi için çaIışmalara başlanmıştır (Özgüç 1986, 38). 1934-1938 yıllarını kapsayan Birinci Beş Yıllık Sanayileşme Planı hazırlanmış ve bir önceki döneme göre devlet daha etkin bir rol oynayarak sanayileşmenin ilk önemli adımlarını atmıştır. Bu dönemde kimya, pamuklu dokuma, kağıt ve selüloz, kamgarn, kendir, demir, kükürt, cam-seramik ve şeker sanayi alanlarında önemli yatırımlar yapılmıştır. 1950’lerden sonra ise özel sektörün güçlenmesi ve dış yatırımların artması ile Türkiye'de sanayi üretim hızlı bir gelişme göstermiştir (Özgüç 1986, 40). Son dönemde ise Türkiye'nin göreceli kısa endüstriyel tarihinde sanayi faaliyetlerin azalmasında etkisi olan doğa, kültür ve spor turizmi yatırımlarının ön plana çıkması, yurt içi ve yurt dışı turizmin ülke ekonomisine katkısının artması gibi hizmet sektörüne yönelik unsurlar İspanya gibi Güney Avrupa ülkeleriyle benzerlikler göstermektedir (Pozo ve Gonzalez 2012, 447-448).

Sanayi devrimin çok katmanlı etkilerinden biri devrimin fiziksel yansıması olarak mekânsal planlama ve yapı mimarisine yaklaşımda kendisini göstermektedir. Hızla artan kent nüfusu ve oluşmakta olan yeni ekonomik sistemin ihtiyacını karşılamaya yönelik olarak kar-zarar ilişkisi gözetilerek planlanan kent ve büyük makinaların yerleştirilebileceği, enerji dağılımının gerçekleştirilebileceği büyük ölçekli taş ve metal fabrika binaları dönemin geleneksel mimari anlayışının yerini almıştır (Bergeron 2013, 33-35). Böylelikle 19. yüzyılın ikinci yarısında itibaren sanayi mimarisi olarak tanımlanan yaklaşım ön plana çıkmıştır. Yeni sosyal düzen ve sanayi mimarisinin yayılımı kırsal yerleşimler ile kent tasarımını ve kentleşme dinamiklerini radikal biçimde etkilemiştir. Ancak, sanayi faaliyetlerinin terk edildiği süreçte kentsel mimaride büyük bir dönüşüme neden olan ve endüstriyel üretime yönelik yapılar da işlevsizleşmeye başlamıştır.

Kültürel miras olgusunun şekillenmeye başlamasıyla, artık kullanılmayan endüstriyel yapılarının miras değeri olarak önemi algılanmıştır. İnsanlık tarihini etkileyen önemli süreçlerden biri olan sanayi devrim yalnızca kent planlamasında değil, toplum yaşamında, bireyselleşme kavramının gelişmesinde, sosyalkültürel ilişkilerde ve ekonomide dönüşüme neden olmuştur. Yanı sıra, daha geniş perspektifte üreten ve güçlenen bir bütünün parçası olma, beceri ve ticari egemenliğe sahip olma durumuyla ilişkili olarak sanayileşme toplumsal aidiyet, tarih ve kimlik algısında etkiye sahiptir. Bilim ve teknolojinin tarihsel gelişiminde ise bir mihenk noktasıdır.

Endüstriyel miras anlayışı, uygulamaları daha önceye dayansa da TICCIH'in (The International Committee for the Conservation of Industrial Heritage, Uluslararası Endüstri Mirası Komitesi) 1978 yılında kurulması ve 2003 yılında hazırlanan ve ICOMOS tarafından da kabul gören The Nizhny Tagil Charter for the Industrial Heritage (Endüstriyel Miras Nizhny Tagil Tüzüğü) ile bilinen ve olgunlaşan bir kavramdır.

Endüstriyel miras olgusunu şekillendiren değerler incelendiğinde geçmişin izlerini taşıyan maddi kalıntıya bağlı arkeolojik anlamlar ilk akla gelenlerdir. Bununla ilişkili olarak gelişen endüstriyel arkeoloji terimi, literatürde ilk olarak 1955 yılında Michael Rix'in “Industrial Archaeology” başlıklı makalesinde kullanılmıştır (Minchinton I983, I25). Sonraki dönemlerde bu alanda yapılan çalışmalar maddi kanıtların endüstriyel alanların anlaşılması ve yorumlanmasındaki katkısını açıkça ortaya koymuştur (Storm ve Olssen 2013, 692-708).

Endüstriyel yapılar mimari ve mühendislik planlama ve tasarımdan şekillenen estetik özelliklere sahiptir. Bu özellikler endüstriyel peyzaj içinde doku ve bileşenlerle kendine özgü bir yapı gösterir. Bu nedenle, kültürel mirasın korunması kapsamında endüstriyel miras alanlarına yapılacak müdahaleler, bu alanların çevresi ile de ilintilidir. Ayrıca fiziksel yapı bağı olduğu somut olmayan kültürel miras unsurları olan, kültürel kimlik ve bellek gibi değerleri ile bütüncül bir yaklaşımı gerektirmektedir.

Endüstriyel miras alanları, güncel yaşam alanları ve yaşam dinamikleri ile genellikle çatışma halindedir. Bu açıdan bu tür kompleks alanların bir bütün olarak korunması sürülebilirlilik kavramı ile yakından ilişkilidir. Sürdürebilirliğin kavramsal çerçevesine ilişkin genel bir uzlaşma olmasına karşın uygulamalar halen tartışmalıdır (Landorf 2009, 495). Endüstriyel mirasla ilgili çalışmalarda sürdürebilirlik; kültürel-sosyal sürdürebilirlik, sürdürülebilir kalkınma ve yeniden işlevlendirilen yapıların finansal sürdürülebilirliğinin sağlanması alt başlıklarında değerlendirilmektedir (Landorf 2009; Pozo ve Gonzalez 2012; Falconer 2006; Bergeron 2012; Özdemir 2009). 
Terk edilmiş endüstriyel alanların korunması genellikle bu yapıların yeniden işlevlendirilmesi ile gerçekleştirilmektedir. Yeniden işlev verilerek gerçekleştirilen ve sürdürebilir bağlamında başarılı koruma projeleri arasında Essen Almanya'daki Zollverein Colliery endüstriyel kompleksi (Copic vd. 2014; Loures 2015), Liverpol İngiltere'de Royal Albert Dock (Falconer 2006, 56; Rodwell 2008), San Francisco Amerika'da bulunan Ghirardelli Meydanı (Isenberg 2010) sayılmaktadır.

Zollverien Colliery kömür işletmesi, Ruhr bölgesinin (Almanya) 19. yy. ortalarında başlayan sanayileşme sürecinin devamı olarak 1932 yılında açılmış ve 1986 yılında kapatılana kadar Alman sanayisinin en ünlü simgelerinden olmuştur (Dordevic vd. 20I4, 46). IBA (International Building Exhibition) Emscher Park Dönüşüm programı kapsamındaki fabrika alanı Bauhaus stilindeki mimarisi ve tarihsel konumu itibariyle taşıdığı özgün değerler nedeniyle 200I yılında Dünya Kültür Mirası listesine alınmıştır. 100 hektarlık alana sahip kompleks Ruhr Müzesi, Endüstriyel Miras Ana Girişi, Zollverein anıtsal yolu, Güneş Çarkı ve havuz olarak tasarlanmış bir yerleştirme alanı gibi bölümlerden oluşmakta ve yılda yaklaşık 1500000 kişi tarafından ziyaret edilmektedir. Fabrika alanın dönüşüm projesi, bireyin ve toplum belleğinin organik karşılığını sergilemesi ve bölgesel müze örneği olarak özgün dokusunu koruyarak simgeleştirmesi ile önem kazanmaktadır.

1846 yılında hizmete giren dönemin önemli deniz ticaret merkezlerinden Royal Albert Dock liman ve tersanesi zamanla teknolojik gelişimlerin arkasında kalması ve altyapı yetersizliğinden işlevsiz hale gelerek 1972 yılında kapatılmıştır (Falconer 2006, 56). 80'lerde Liverpool'da yaşanan huzursuzluğun çözümü ve kentte pazar ekonomisinin yeniden canlandırılması için kurulan MCD (Merseyside Development Corporation) şirketi tarihi belgelerin incelenmesi ve hassas alan etütleri ile liman alanının özgün teknolojik yapısını ve tarihsel değerini ortaya çıkarmıştır. Sürdürülebilir kalkınma modeli ve endüstriyel alanın dönüşüm projesinin entegrasyonu ile liman ve liman alanında yer alan depo binaları kademeli olarak Tate Liverpool, Merseyside Deniz Müzesi, Beatles Müzesi, Granada Televizyonu haber merkezi, restoranlar ve konut olarak korunmuş, böylelikle istihdam sağlanmış ve Royal Albert Dock cazibe merkezi haline gelmiştir.

San Francisco'da bugün Ghirardelli Meydanı olarak isimlendirilen alanda 1895 yıllında konumlandırılan Ghirardelli Çikolata Fabrikası, 1960 yılında kapatıldığında kent sakinlerinin oluşturduğu bir grup tarafından satın alınmıştır. Böylelikle eski fabrika alanında alışveriş ve yiyecek-içecek mekanları tasarlanmış ve meydan 1964 yılında ziyarete açılmıştır (Fragner 2006, II2). Ghirardelli Meydanı ABD'nin en erken yeniden işlevlendirme projesi olarak ardılları için kentsel dönüşümde koruma ilkeleri ile uyumlu bir örnek oluşturmuştur.
Türkiye'de yeniden işlevlendirme ile gerçekleştirilen uygulamaların 1980'li yıllarda Haliç'te bulunan üretim yerlerinin tescillenmesi ve restorasyon projelerinin hazırlanmasıyla başlamış olduğu kabul edilmektedir (Saner 2012, 60). Ancak bu ilk örnekleri endüstriyel mirasın korunması kavramıyla ilişkili olarak değil, tescilli binaların mimari restorasyon ile kentsel hayata kazandırılan projeler olarak kabul edebiliriz. 1990'lı yıllarda ise endüstriyel miras kavramının ülkemizde daha yaygınlaşmamış ve endüstriyel alanların teknolojik gelişim ve ihtiyaçların değişimi ile terk edilmesi ile bu yapı komplekslerinin koruma projeleri sivil inisiyatiflerin de müdahaleleri ile gerçekleştirilmiştir. Bu tür uygulamaların daha önceki dönemlere göre en önemli farkı, endüstriyel mirasın bütüncül yaklaşımını, kent belleği ve kolektif bilinç unsurları kaygılarını taşıyor olmalarıdır (Cihanger 2012; Yılmaz 2014; Oğuz, Saygı ve Akpınar 2010).

Endüstriyel miras alanların bütüncül yaklaşımla fiziki yapısının yeniden işlevlendirme ile korunmasına ilişkin olarak yapılacak planlamalar ve sonrasında uygulanacak yönetim stratejilerinin değerlendirilmesinde dört anahtar sürdürülebilirlik kriteri belirlenmiştir (Landorf 2009).

I. Durum analizi: Yapının planlanması aşamasında iç ve dış etmenlerinin tanımlanıp tanımlanmadığının belirlenmesi

2. Stratejik çevre uyumu: Planlamanın uzun vadeli ve bütüncül olmasının değerlendirilmesi

3. Paydaşların ortak değerleri: Yerel yönetimler, sivil dinamikler, finansal kaynaklar, koruma uzmanları gibi paydaşların değerleri, ihtiyaçları ya da beklentilerinin yapının korunması planlamasında stratejik vizyon çerçevesine dahil edilip edilmediğinin incelenmesi

4. Paydaşların katılımı: Paydaşların karar alma süreçlerine katılımının kapsamı ve derecesinin saptanması

Bu kriterler üzerinden değerlendirildiğinde, belirli bir endüstriyel miras alanının mekânsal ve zamansal katmanları ile organik bağlarını ortaya çıkarmak mümkün olmaktadır. Ayrıca bu tür bir yaklaşım planlama ve uygulama aşamasında kentsel arkeolojisi, mimari restorasyon, peyzaj mimarlığı, mimarlık tarihi ve koruma gibi ilgili uzmanlık alanlarının tümünün etkileşimli olarak çalışması gerekliliğini de göstermektedir.

Bu bağlamda, çalışmada Türkiye'nin önemli endüstriyel miras alanlarından SEKA Kağıt Fabrikası'nın tarihsel süreçte değişimi, İzmit belleğine katkısı incelenerek bilim merkezi ve kağıt müzesi olarak onarımı ve yeniden işlevlendirilmesi yukarıda belirtilen kriterler açısından değerlendirilmiştir. Ülkemizde sanayi üretimin başladığı kurumlardan biri olan SEKA'nın mimari dönüşümünün yanı sıra Cumhuriyet'in kuruluş tarihindeki büyük sosyal değişimlerin bir yansıması olan fabrika yerleşkesindeki maddi değerlerin ve yaşam izlerinin dijital görüntüleme yöntemleri ile aktarılması için kullanılan uygulamalar tanıtılmıştır. Çağdaş müzecilik sergileme anlayışına uyumlu olacak 


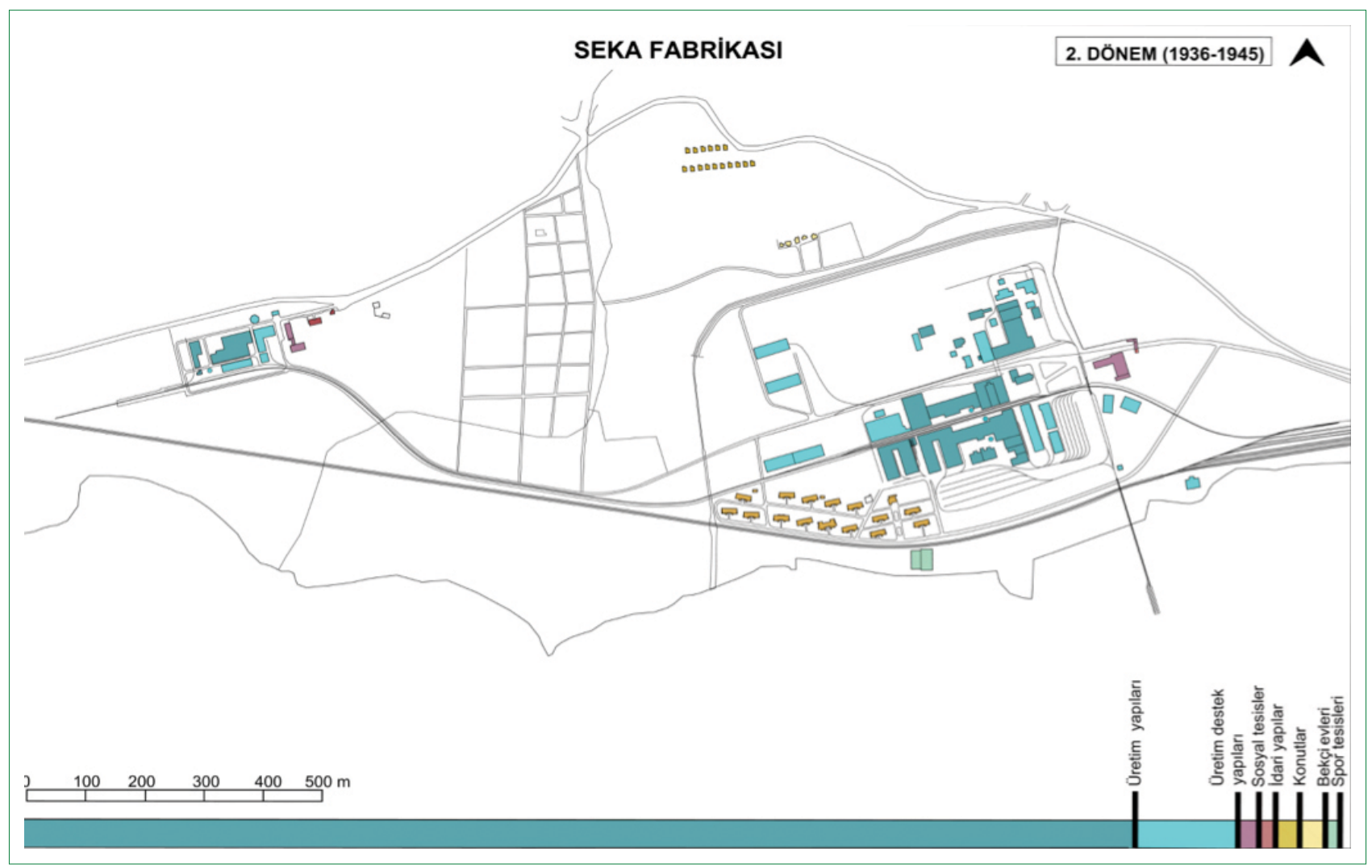

Şekil I. 2. Dönem (1936-1945) SEKA Kağıt Fabrikası yerleşke planı. https://www.izmitteseka.com/mimari

şekilde geliştirilen uygulamaların, mevcut sergileme teknikleri ile karşılaştırıldığından ziyaretçi algısına katkıları incelenmiştir. Fabrika binasının görsel kimliğinin bir sanat objesi olarak yeniden şekillendirilmesi ve arttırılmış gerçeklik teknolojileri aracılığı ile zamansal katmanların gözlemi yöntemi kullanılarak iki etapta yapılan çalışmalar, hedef kitle olan ziyaretçilerden alınan geri dönüşler ile birlikte değerlendirilmiştir.

\section{SEKA Kağıt Fabrikası, Yerleşkesi ve Sosyo- Kültürel Değişim}

Cumhuriyetin ilk yıllarında ülke sanayisi örgütleşme düzeyi, teknolojik alt yapısı ve üretim cinsleri bakımından henüz çok ilkel bir düzeydedir ve kağıt sanayisi de bununla ilintili olarak ağırlıklı ithalata dayanmaktadır (Kocabaş vd. 1996, 43). 1920'li yılların sonundan itibaren yerli kağıt üretim fikri canlanmış ve bu doğrultuda incelemeler başlatılmıştır. İktisat Vekaleti tarafında en hızlı şekilde ülkede üretim gücünün ve yerli üretim mallarının tüketiminin arttırılmasına yönelik bir sanayi programının hazırlanmasına karar verilmiştir (Dölen 20I5, 329). Hazırlanan raporda kağıt sanayisinin kurulması konusu da ele alınmış ve günlük 60 ton kağıt ihtiyacının 40 tonunu karşılamak üzere üretim yapacak bir fabrikanın kuruluş maliyetlerine yer verilmiştir. 1934 yılında yapılan tetkikler ve keşif çalışmaları sonucu hazırlanan raporlarda Birinci Sanayi Planı'nda belirtilene uygun olarak su temini, arazi topografyası ve nakliye olanakları gibi kriterler açısından kurulacak fabrikanın yeri İzmit olarak belirlenmiştir (Kocabaş vd. 1996, 66). I. Kağıt Fabrikası olarak bilinen İzmit Kağıt fabrikasının temelleri I4 Ağustos 1934 yılında, fabrika için ayrılan $121.864 \mathrm{~m}^{2}$ alanda Başvekil İsmet İnönü tarafından atılmıştır (Dölen 20I5, 336). 1936 yılı Nisan ayında fabrika ilk deneme üretimini yapmış ve aynı yıl Kasım ayında İktisat Bakanı Celal Bayar tarafından açılmıştır. Dönemin medya kanallarında "medeniyet” ile ilişkilendirilen kağıdın artık ülkemizde üretilebiliyor olması büyük sevinç ve heyecanla karşılanmıştır. Böylelikle Kağıt Fabrikası, genç Cumhuriyet'in diğer birçok alanda yaşanan devrimleriyle biçimlenen sanayileşme ve yerli üretim hamlesinin gerçekleşmesinde önemli bir role sahip olmuştur (Şekil I).

SEKA Kağıt Fabrikası sanayi ve kalkınma alanındaki başarıların bir örneği olmasının yanı sıra, endüstriyel miras kapsamında değerlendirildiğinde sosyal ve kültürel yaşamda etrafında yaratığı büyük değişim ile de önem taşımaktadır. Fabrikanın kuruluşunun ilk yıllarında başlayan düzenlemeler etkilerini ilerleyen yıllarda fabrika çalışanları arasında ve İzmit kent yaşantısında göstermiştir.

Fabrikanın inşası ve üretime geçmesi ile Alman uzmanların Türk meslektaşlarına bilgi ve deneyim aktarımına dayalı eğitim alanında başlayan faaliyetler, 1939 yılında açılan kurslarla devam etmiştir (Kocabaş vd. 1996, I68-I7I). 194I itibariyle 


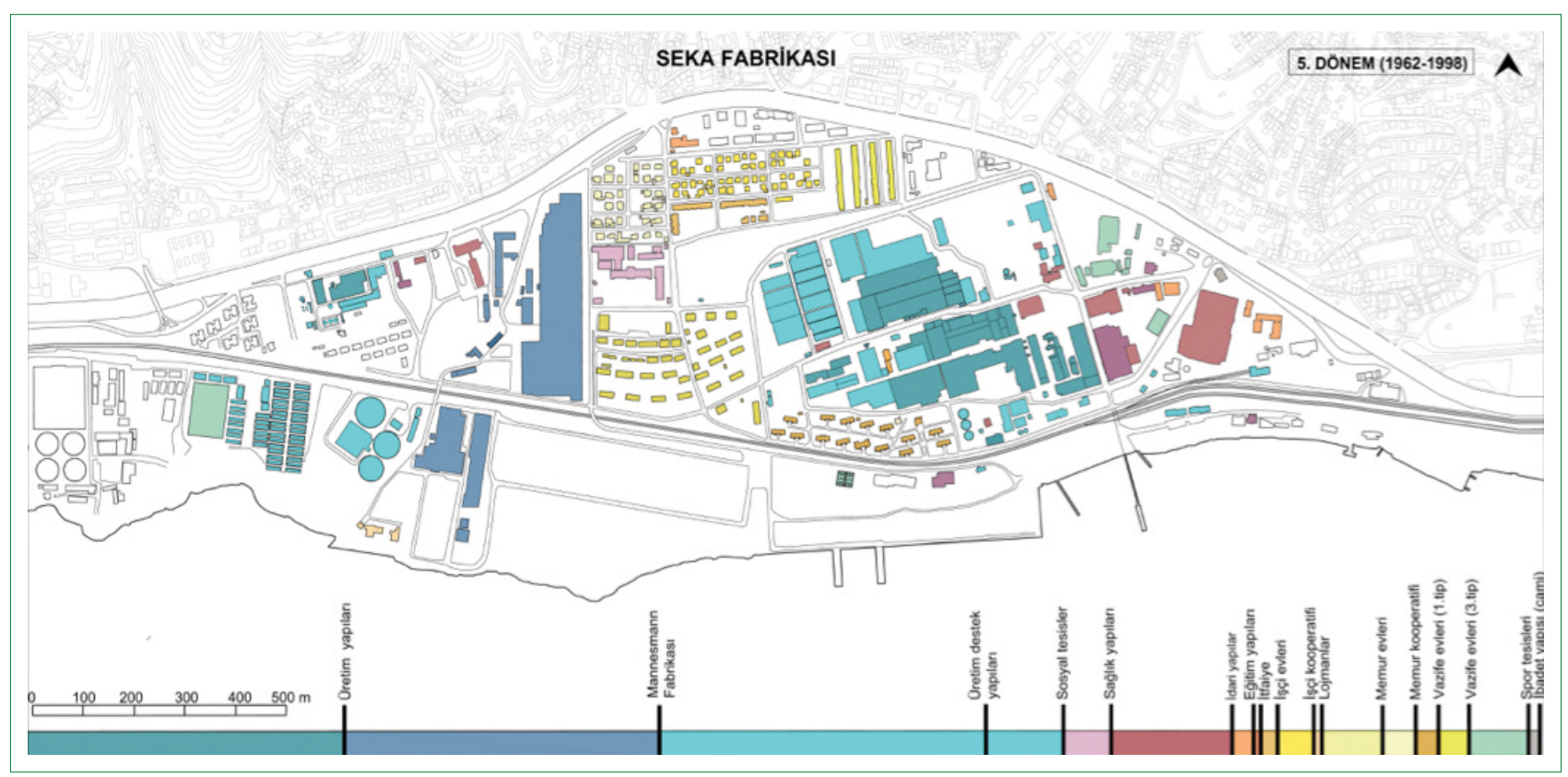

Şekil 2. 5. Dönem (1962-1998) SEKA Kağıt Fabrikası yerleşke planı. https://www.izmitteseka.com/mimari

verilen hizmet içi kurslar daha sistematik ve standart bir yapıya sahip olmuş ve yurtdışı eğitimine öğrenciler gönderilmiştir. Eğitimleri örgün hale getirebilmek için 1944 yılında "Selüloz Sanayi Müessesi Çırak Okulu” ve 1945 yılında 250 öğrenci kapasiteli "Sümer Okulu” ilkokulu fabrika yerleşkesi alanında kurulmuştur.

Sosyal örgütlenme faaliyetleri de 1937 yılında kurulan tüketim kooperatifi, 194I'de hizmete geçen revir ve 1943 yılında fabrika yerleşkesinde işçi evleri inşatları ve çalışanların sosyal ihtiyaçlarını karşılamak üzere yapılan kantin, yemekhane, sinema salonu, lokal ve çocuk bahçesi yapılmıştır ile hızla gelişmiştir (Kocabaş vd. 1996, I7I-175, Dölen 20I5, 430). 1956 yılında yayın hayatına başlayan SEKA Postası ile kurum içi iletişim hizmetleri 1984 yılına kadar düzenli olarak devam etmiş ve kentin sosyal yaşamında önemli bir kaynak oluşturmuştur (Şekil 2).

1937 yılında kurulan SEKA Kağıtspor kulübü güreş, boks, futbol, basketbol, atletizm, kürek ve yelken gibi farklı branşlarda ulusal ve uluslararası başarılar sağlayarak kentin spor yaşamına ve sporun gelişimine katkı sağlamıştır.

Bu etkinlikler birlikte değerlendirildiğinde, Kağıt Fabrikası'nın Cumhuriyet Dönemi değişim sürecinin önemli bir göstergesi olduğu anlaşılmaktadır. Fabrika ve yerleşkesi asıl hedef olan yerli üretim sanayinin gelişmesine katkısı olan bir mekân ötesinde, öncelikle fabrika çalışanları ve İzmit halkının yaşamında sosyal ve kültürel alanda yaşadığı, tanık olduğu düzenli değişikliğe ivme kazandırmış olması bağlamında kent belleğinde yer eden özgün bir değerdir. Bu nedenle endüstriyel mirasın ko- runmasında sürdürülebilirlik kriterleri arasında belirtilen bütüncül yaklaşımı ve yerel paydaşların katılımının sağlanabilmesi açısından önem taşımaktadır.

\section{İzmit SEKA Kağıt Fabrikası'nın Yeniden İşlevlendirilmesi}

80’li yıllar itibariyle özel sektörün kağıt sanayisine yatırımları artarken, İzmit Kağıt Fabrikası'nın, teknolojik gelişmelere ve çevresel gerekliliklerine ayak uyduramaması, verimli işletilememesi, maddi yatırımların bütçesi ve kentsel nüfusun artması gibi nedenlerle 1998 yılında Özelleştirme Yüksek Kurulu fabrikanın kapatılmasına karar vermiştir. Ancak fabrikanın, İzmit belleğinde ve yaşantısındaki etkisi nedeniyle halkının ve çalışanlarının yoğun tepkisi ile karşılandığından, özelleştirme işlemi bir ay sonra iptal edilmiştir. 2005 yılında ise hükümet ve sendika arasında yapılan protokol sonucunda SEKA İzmit İşletmeleri çalışanları ve tüm varlıkları ile Kocaeli Büyükşehir Belediyesi'ne devredilmiştir. Protokolde fabrika yerleşkesinin halka açık yeşil alan ve rekreasyon alanı amaçlı devredileceği hükmü de yer almaktadır.

Bu tarihten sonra yerleşke Bursa Kültür ve Tabiat varlıklarını Koruma Kurulu'nun 2005 yılı kararı ile “Koruma Amaçlı İmar Planı ve İmar Revizyonu Yapılacak Alan” olarak belirlenmiştir (Aydın ve Kartal 20I0, 22). SEKA Kent Parkı olarak yürütülen proje üç etap olarak kurgulanmıştır (Şekil 3). İlk etap 2007 yılında tamamlanmış ve sahil kesiminde bulunan liman bölgesi kamusal işleve sahip ve körfez boyunca yeşil alan sürekliliğini sağlama amacına yönelik olarak çok amaçlı parka dönüştürülmüştür (Oğuz, Saygı ve Akpınar 2010, I6I). 


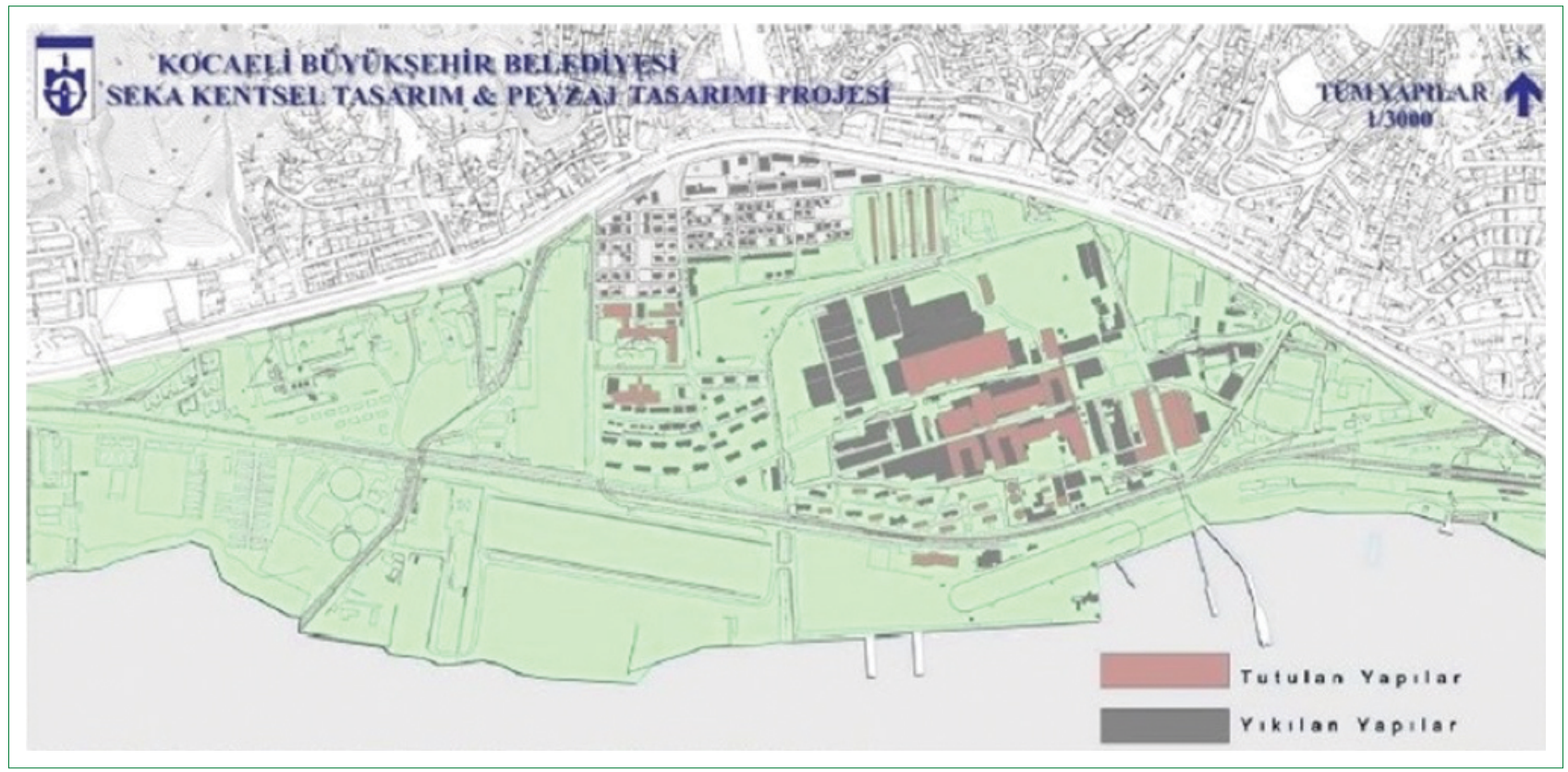

Şekil 3. SEKA Kentsel Tasarım ve Peyzaj Tasarım Projesi

İkinci etapta ise fabrika yapılarının yoğun olduğu alanda şekillenmiş ve yeniden işlevlendirmeye yönelik etütler yapılmıştır. Aydın ve Kartal tarafından yapılan mimari analizlerde SEKA I. Kağıt Fabrikası'nın bozulma durumları ve koruma sorunları tespit edilmiştir (20I0). Bu çalışmaya göre I. Kağıt Fabrikası binasının mimari ve taşıyıcı sistemin mevcut durumu açıdan yeniden kullanılmaya uygun olduğu belirtilmiş ve fabrikanın üretim ünitesinin cephe düzenini bozmuş olan işçi soyunma odası, elektrik bakım ünitesi gibi yaklaşık $1500 \mathrm{~m}^{2}$ alanın yıkılması ve güncel yönetmeliklere uygun hale getirilmesi önerilmiştir. Yapılan çalışma sonucunda, fabrika alanının yeniden işlevlendirilmesinde endüstriyel mirasa ait izlerin mümkün olduğunca yerinde korunması ve özgün mimari özelliklere en az müdahale yapılması prensiplerinin yapının fıziki özellikleri ve kent gereksinimleri doğrultusunda belirlendiği belirtilmiştir (Aydın ve Kartal, 2010). Bu prensiplere uygun olarak müze ve kültürel ve eğitim amaçlı kullanılacak alanlar saptanmış ve SEKA park alanı ile organik ilişki içinde bir cazibe merkezine dönüştürülmesi önerilmiştir. Ancak bu öneriler, fabrikanın mimari yapısı üzerinden, mimari restorasyon ilkeleri ve peyzaj özellikleri göz önünde bulundurularak yapılandırılmıştır. Çalışmada diğer bir öneri olarak bahsedilen kağıt üretiminin sürdürülmesi ve sürdürülebilirlik kapsamında kar amaçlı olarak satılması ise endüstriyel alanların yaşatılarak korunmasındaki bütüncül yaklaşıma uygundur.

2009 yılında alanda Kocaeli Büyükşehir Belediyesi yürütücülüğünde KA.BA. Eski Eserler Koruma ve Değerlendirme Mimarlık bünyesinde I. Kağıt Fabrikası'nın Koruma Onarım ve Yeniden İşlevlendirme Projesi çalışmaları başlamıştır. Yeniden işlevlendirme planlamasında: a) I. Kağıt Fabrikası - Kağıt Müzesi ve Bilim Merkezi

b) Taşlı Değirmen - Kağıt Müzesi Ek Yapısı

c) Mekanik Atölye - Bilim Merkezi Ek Yapısı

olarak kurgulanmıştır. KA.BA firmasının yaptığı ön etütlerde fabrikanın kapanmasından sonra geçen dört yıl içerisinde bazı önemli ekipmanın satıldığı ve mevcut durumun belgeleme çalışması yapmak için zor bir hale geldiği bildirilmiştir. Buna karşın alanın ve içerisindeki endüstriyel miras unsurlarının “... teknolojik özelliklerini yansıtması, kurucularının ve çalışanlarının hikâyelerini bizlere anlatması bakımından "Kağıt Müzesi ve Bilim Merkezi” olarak yeniden işlevlendirilen yapının, içindeki her türlü makina, cihaz, tesisat ve aksam dahil olmak üzere tüm unsurlarıyla korunması amaçlanmıştır" (Arkiv). Bu doğrultuda yapılan işlemler ve müdahaleler modern koruma ilkeleri ile uyumlu olarak binanın ve içeriğinin yaşanmışlıkları ile korunmasına yönelik olmuştur. Çalışır durumdaki makinalarda ziyaretçilerin baskı işlemleri deneyimlemesi hedeflenmiştir.

Fabrikanın kimliği ve belleği gezi güzergahı boyunca, müze arşivinde bulunan malzemeler, belgeler, fotoğrafların yerleştirilmesi ve eski fabrika çalışanları ile gerçekleştirilen sözlü tarih çalışmalarının ekran ve projeksiyonlardan gösterilmesi ile aktarılmaya çalışılmıştır. Ancak, kağıt üretim süreçlerinin anlatıldığı kağıt müzesi yaklaşımını ve bunun yanı sıra Nikomedia tarihi içerikli sergilemeler SEKA Kağıt Fabrikası'nın bütünlüğüne zarar vermekte ve anlam karmaşası yaratmaktadır.

Kağıt Fabrikası'nın dönüşüm ve yeniden işlevlendirilmesi projesini değerlendiren akademik incelemelerden biri Sekapark alanını yakın çevresi ve kıyı kullanımına etkisi açısından incelemiştir (Uzun 2014). Çalışmada, proje öncesi veriler değerlen- 
dirildiğinde alanın işlevini yitirmiş, kent içi değerinin kaybetmiş, kentin kıyı ile bağlantısını kesen ve sürdürülebilir kullanımı engelleyen bir çöküntü sahası olduğu belirtilmiştir. Projenin etkilerini doğal ve beşeri alanda olmak üzere iki başlıkta sunulmuştur. Buna göre fabrikanın yaptığı olumsuz etkilerin kaldırılmış, bitki topluluklarının korunması ve ağaçlandırma ile yeşil alanlar yaratılmıştır. Beşeri etki ise park alanında yaratılan yürüyüş yolları, spor ve oyun alanları, dinlenme alanları, bilim merkezi ve müze gibi yeni kullanım türleri ile kıyı alanının şehir halkı için önemli bir sosyal alan şeklinde tasarlanması olarak değerlendirilmiştir. Diğer bir çalışmada ise SEKA Endüstriyel Dönüşüm Projesi, kentsel yasarım, peyzaj mimarlı̆̆ı ve sürdürülebilir çevre kapmasında incelenmiştir (Oğuz, Saygı ve Akpınar 2010).

SEKA Kağıt Fabrikasının, Kağıt Müzesi ve Bilim Merkezine dönüşümünü mekânsal bellek göstergeleri üzerinden inceleyen çalışmada ise mimari kimliğin, özgünlüğün, estetik ve anı değerleri korunarak Müze'de mekânsal bellek sürekliliğinin sağlandığı belirtilmiştir (Çakır ve Gönül 20I5).

Cumhuriyet döneminin kamusal yapılarının ve alanlarının kolektif bellekteki değişkenlerini ortaya koyarken algıdaki sonucunu saptamaya yönelik bir araştırmada, SEKA yerleşkesinin sosyal yapılarının korunamaması, dolayısıyla SEKA yerleşkesinin bütüncül haliyle değerlendirilememesinden bahsedilmiş ve denizle ilişkiyi kuran Sekapark'ın eski SEKA ile bağlantıyı kuramaması anlatılmıştır (Erol 2017, 95).

Sözü edilen çalışmalar ve yapılan mekan incelemeleri SEKA Endüstriyel Dönüşüm ve Yeniden İşlevlendirme projesi I. Kağıt Fabrikası bazında değerlendirildiğinde, Kağıt Müzesi'nin modern koruma ve onarım anlayışıyla uyumlu olarak sosyal içeriği ve kentsel bellekteki yeri de göz önünde bulundurularak tasarlandığını söylemek mümkündür. Ancak, kağıdın hikayesinin anlatıldığı bir kağıt müzesi kurgusu, İzmit Kağıt Fabrikası'nın özgün mimari ve teknolojik özelliği ile sosyal katmanlarının aktarılmasında bütünlüğünü bozmaktadır. Aslında, ziyaretçilerin müzeye girdiklerinde İzmit Kağıt Fabrikası'ndaki kağıt üretimini ve işçilerin fabrika içi ve dışı yaşamlarını “izmit Kağıt Fabrikası Müzesi” gezi güzergahı boyunca takip etmeleri, fabrika endüstriyel alanının soyut mirasının korunmasında daha etkili bir yaklaşım olacaktır.

Bu değerlendirme doğrultusunda, çalışmada Müze'nin mevcut durumunda endüstriyel mirasın ziyaretçiye kent ve mekan belleği ilişkisi içinde aktarılması için koruma ilkeleriyle uyumlu olarak çağdaş müzecilik ve sergileme tekniklerinin ve dijital görüntüleme biçimleri bir alternatif olarak kullanılmasının etkileri incelenmiştir..

\section{Bir Kent Bir Mekan - SEKA Kağıt Müzesi Fotoğraf Sergisi}

Görmeyi ve görselliği kuramsallaştıran "Camera Obscura”
Platon'dan günümüze izleme geleneğini inşaa ederek ve teknolojik devinimler eşliğinde gelişen seyretme ritüelinin en önemli yapıtaşını oluşturmuştur. Temsilde gerçek gibiliğe doğru sürekli ivmelenen bir gelişimi temel alan camera obscura bu sürecin sonunda fotoğraf makinesine evrimleşmiştir (Crary 2004, 39). Bilim ve kültür tarihinde camera obscura, 17. ve 18. yüzyıl Avrupa'sında gözleme dayalı bilimlerin gelişiminde kullanılmıştır. İlkel fotoğraf makinesini oluşturan camera obscura ile fotoğraf temelli görmenin zemini oluşturulmuştur. Ardından gelişen "görmenin sürekliliği” (sinema) kavramı ile hareketli görüntü izleme başlamış ve görme bir çeşit daha evrilmiştir.

Gözlemcinin görme ve izleme algısını değiştiren bir diğer gözlem biçimi diaromalardır. Diaroma, optik deneyimin önceden tasarlanan zamansal seyrine dayanmaktadır (Crary 2004, 125). Fotoğrafın dışında 19. yüzyıldaki en önemli imge üretimi aygıtı stereoskoptur. Stereoskop, fotografik imgelere boyut hissi vererek görmeyi sağlayan araçtır. Hareket yanılsamasına yarayan bu alet gözlemleme algısında değişiklik yapmıştır.

Illk insandan itibaren var olan izleme yöntemi ile bilgi aktarma, günümüz müzecilik kavramını yaratmıştır. Bugünkü anlamda müzenin ortaya çıkışı ise 15. yüzyıla rastlamaktadır. Geçmiş dönemde müzecilik anlayışı ile günümüz müzecilik anlayışı arasında geçen süreçte teknoloji ve toplumsal hayattaki değişimleri ile sergileme ve izleme deneyiminde farklılıklar gerçekleşmiştir. Modern müzelerinin ortaya çıkması ile sergileme tavırlarındaki değişiklikler müzeleri ziyaretçi bekleyen kurum olmaktan çıkartıp ziyaretçi çeken kurum olarak yeniden tasarlanmasını gerektirmiştir (Altunbaş ve Özdemir $2012,10)$. Çağdaş müzecilik yaklaşımında, müze ve izleyici arasında iletişimin kurulması önemlidir. Rehberler eşliğinde ziyaretler yapılırken, film gösterileri izlenerek, seminerler düzenlenerek, atölye eğitim uygulamaları ile bilgisayar destekli sergi gibi teknolojiler kullanılarak etkili bir sunum gerçekleştirilmektedir (Erbay 20I I, 75). Çağımı dijital görüntüleme yöntemi pek çok algımıza hitap eden izleme deneyimleri sunmaktadır. Görüntüleme biçimlerindeki bu değişim bilginin paylaşımı, öğrenme eyleminin yeniden tasarlanması gibi alanlarda pek çok olanak sunmaktadır.

SEKA Kağıt Müzesi yapı bütününün evrildiği form olan endüstriyel tesis olma özelliği ve çağdaş bir sunum imkanı oluşturularak yeniden tasarlanan sergileme alanları ile sıra dışı bir görselliğe sahiptir. Bu görsel kimlik Kocaeli Üniversitesi Güzel Sanatlar Fakültesi Fotoğraf Bölümü Mimari Fotoğraf dersi kapsamında, fotoğraf ile kayıt altına alınmıştır. Kağıt Müzesi'nin yapısal niteliklerinin etkili bir biçimde yansıtılması, çok yönlü üretim ve dönüşüm çeşitliliğinin tespiti ve kent kimliği içerisindeki kültürel yeri aktarılmıştır. Müzenin mevcut fiziki yapısı gözetilerek teknik mükemmellikte fotoğraflar üretme hedefi ile yapılan bu çalışmada, mimari yapının işlevsel ve biçimsel formları en doğru hali ile kayıt altına alınmıştır. 
Fotoğraflar doğrudan bakış açısı ile yapı içerisinde kapladıkları alanın tamamının görünebilir olması esası ile konunun karşısından geniş bir açı ile görüntülenmiştir. Herhangi bir optik yanılsama ve deformasyona izin verilmeksizin yapının tüm işlevini ortaya koyan yalınlıkta görüntülenen fotoğraflar, optik biliminin doğası gereği var olan görüntü deformasyonu sorununu ile karşılaşıldığında masaüstü yazılım programlarının düzeltme uygulamalarıyla mükemmelleştirilirmiştir.

Çalışma sırasında SEKA kağıt fabrikasının fiziki yapısı ile ilişkili olarak karşılaşılan sorunların arasında, mekanın büyüklüğü ve müze sergileme unsurlarından biri olarak kullanılan yapay ışıklandırmanın birbirinden farklı renk ısılarına sahip olmasıdır. Çoklu renk ısısında ışıklandırmanın birlikte kullanıldığı mekanda başarılı bir fotografik sonucun temelini oluşturan pozlama konusu zorlayıcı bir unsur olmuştur. Bu sorun yardımcı ışık kaynaklarının kullanımı, artı eksi poz değerleri ile yapılan çekim taraması ve HDR yöntemi çekim uygulaması ile ortadan kaldırılmıştır. Mekanın yükseklik ve genişlik açısından tek bir karede görüntülenebilmesi sorunu, panoramik çekim tekniğinin uygulanması ile giderilmiştir. SEKA Kağıt Müzesi'nin içinde var olan endüstriyel makinaların ayrıntı çekimlerinde konu daha kolay fotoğraflanabilmiştir. Fotoğraflar üretim aşamasında tripod ve görmeyi mükemmelleştirmek için gerekli objektif açıklı̆ı̆na uygun araçlar ile çekilmiştir. Konunun doğal ışı kaynağı aracılığı ile doğru aydınlanmasının hangi zaman diliminde olduğu saptanmış, fotoğraf çekimi hava koşulları takip edilerek tamamlanmıştır.

Dış mekanda yapılan çekimlerde SEKA Kağıt Müzesi ve kültürel bellek kavramı üst üste getirilmeye çalışılmıştır. Kocaeli kentinin şehir panoramasının arka fonu oluşturduğu müze fotoğrafları aynı zaman da kentin kültürel belleğinin arşivi olarak gelecek dönemlere bilgiler sunacaktır.

Fotoğraflar, 2017 Aralık ayında açılan "Bir Kent Bir Mekan" sergisinde müzenin makine salonunda sergilenmiştir (Şekil 4-6). Sergi yoğun ilgi görmüş ve eski fabrika çalışanlarının aileleri de sergiyi ziyaret etmişlerdir.

Fotoğraf çalışmaları, sergilenme süresinin bitiminin ardından müze yönetimince SEKA Kağıt Müzesi'nin muhtelif salonlarında kalıcı sergi olarak izleyici ile buluşmaya devam ettirilmektedir. Müze'nin aynı zamanda sanat eseri izlemesinin yapılabildiği bir müze özelliği kazanarak çağdaş yöntemler ile üretilen çalışmaların yer bulduğu mekan olarak var olmaktadır.

\section{SEKA Kağıt Müzesi Arttırılmış Gerçeklik Projesi}

Arttııılmış gerçeklik (AG) arkeolojik sit alanları ve müzeler gibi kültürel miras alanlarında son yıllarda yaygınlaşarak kullanılan yeni medya araçlarından olmuştur. AG teknolojisinin somut olmayan kültürel miras örnekleri üzerine uygulanabilirliği konusunda çalışan Khan ve Byl, sergilemelerde kullanılacak

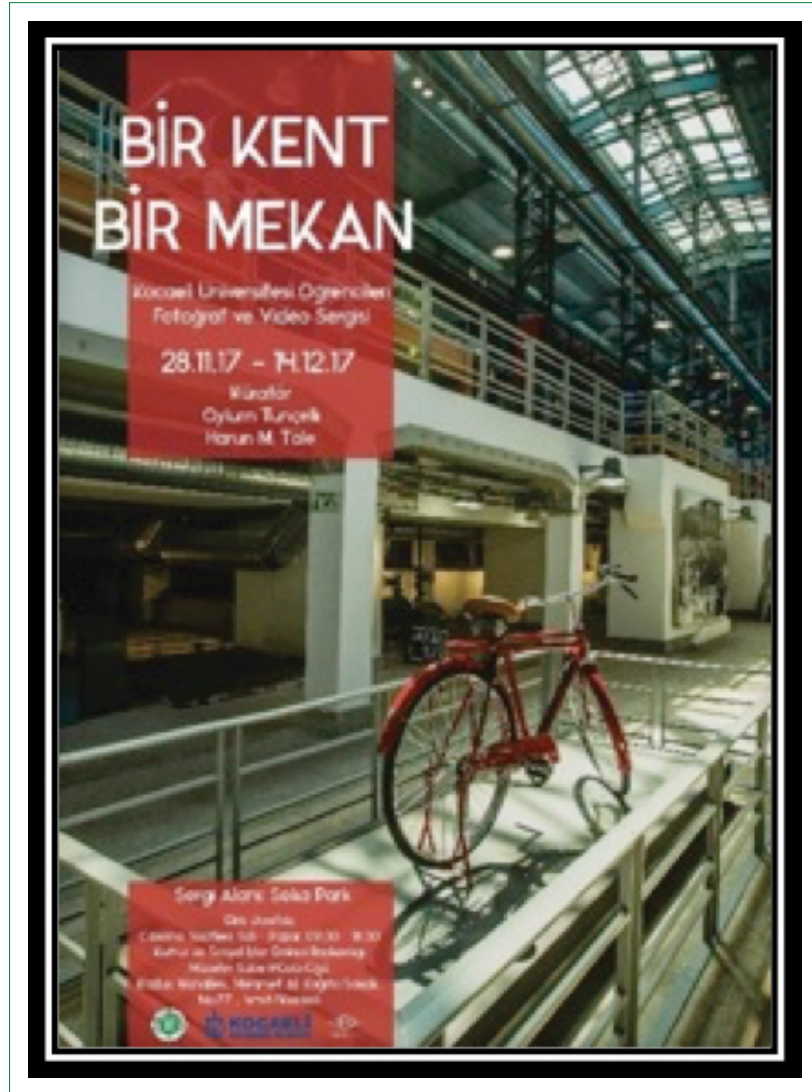

Şekil 4. Bir Kent - Bir Mekan sergi afişi.

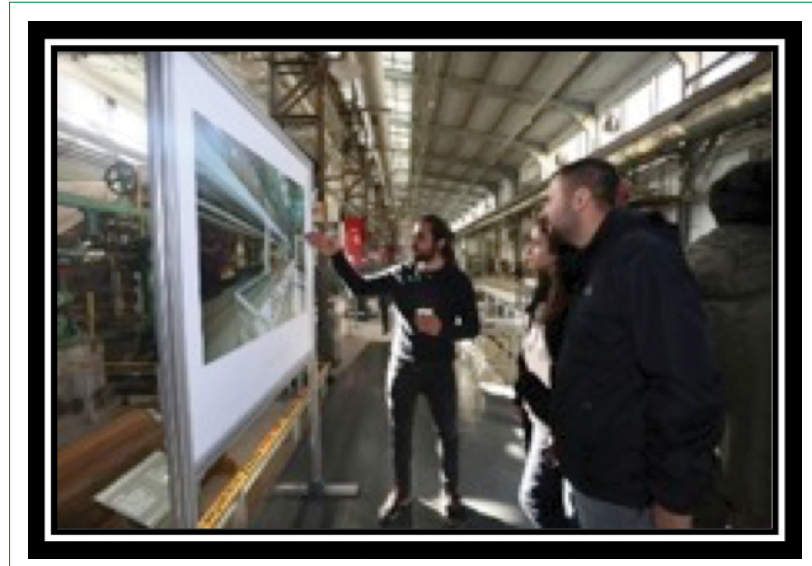

Şekil 5. Bir Kent - Bir Mekan sergisi haber fotoğrafı.

pedagojik içerikli uygulamaların, ziyaretçilerin müzelerde geçirdikleri zamanın kalitesini arttıracağını savunmuştur (20II). $\mathrm{Bu}$ şekildeki müdahalelerin somut olmayan kültürel mirası koruma, anlama ve yeniden canlandırma modellerinde yeni yöntemler oluşturulabileceğini belirtmişlerdir.

Türkiye'de en umut vadeden AG uygulamalarından biri Bostancı tarafından geliştirilen Masaüstü Tarih isimli uygulamadır 


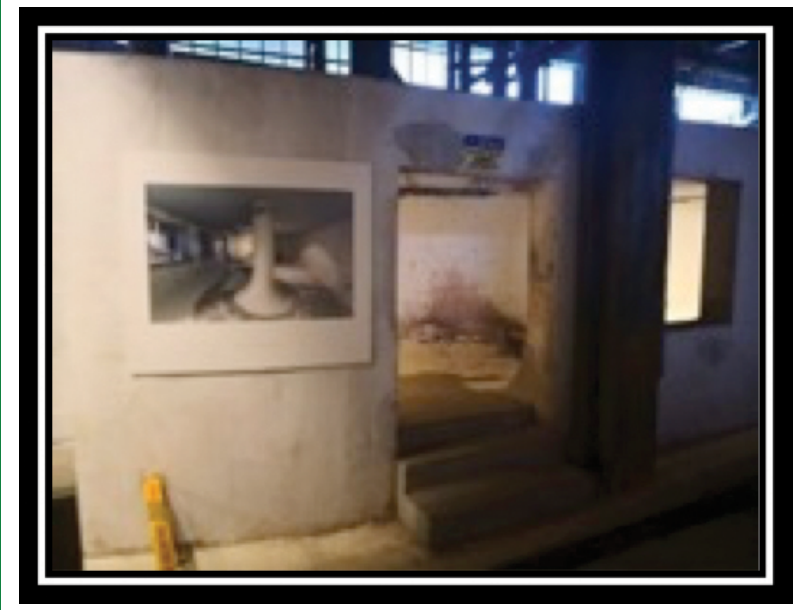

Şekil 6. Bir Kent - Bir Mekan fotoğraflarının müzede sergilenmesi.

(Koyuncu ve Bostancı 2007; Bostancı 20I I). Müzeler kapsamında ise Sakıp Sabancı Müzesi'nde yapılan AG uygulaması en bilinen örnektir. Müzede sergilenen eserler AG uygulaması ile zenginleştirilmiştir ve eserler hakkında detaylı bilgiler veren ögeler oluşturulmuştur. Diğer başarılı bir örnek ise Çorum Arkeoloji Müzesi tarafından kullanılan "Savaş Arabası Simülatörü” dür (Coşkun 2017, 68). Ancak endüstriyel alanlarda AG kullanımı henüz sınırlı sayıdadır. Avustrulya'nın Newcastle kentinde artık kullanılmayan endüstriyel alanların AG ve mobil teknolojiler kullanılarak korunması alternatif ve bütüncül bir model olarak önerilmiştir (Morrison, Gu ve Foulcher 20I2). Slovakya Piestany kentinde yapılan çalışmada ise eski elektrik santralinin yeniden yapılandırılmasında birleşik gerçeklik (sanal gerçeklik ve arttırılmış gerçeklik) endüstriyel miras gelişimde disiplinlerarası işbirliği çerçevesinde geliştirilmiştir (Hain, Löffler ve Zajicek 2016).

SEKA Kağıt Müzesi 12 bin $345 \mathrm{~m}^{2}$ alan üzerine kurulmuştur ve 16 teşhir salonunda Kocaeli tarihi, Mehmet Ali Kağıtçı, kağıdın tarihi ve üretiminin aşamaları, fabrikanın tarihsel süreçleri ve fabrikadaki sosyal yaşamın anlatıldığı farklı konu başlıklarında sergiler bulunmaktadır. Müzede yapılan incelemelerde çağdaş koruma anlayışına uygun olarak restorasyon ve yeniden işlevlendirme planlarında SEKA Kağıt Fabrikası endüstriyel mirasına ait farklı katmanlarının yansıtıldığı; ancak sergilerdeki farklı konu başlıklarının ve müzenin büyüklüğünün, fabrikanın özgün planının anlaşılmasını ve alanın bir bütün olarak algılamasını zorlaştırdığı tespit edilmiştir.

Bu doğrultuda SEKA Kağıt Müzesi kapsamında geliştirilen örnek AG uygulaması, Kağıt Müzesi'nin özgün kullanımı ve kültürel değerlerini ziyaretçilere yerinde ve daha iyi aktarabilmek için kullanıcı kolaylığı ve uygulama maliyetleri kriterleri göz önünde bulundurularak tasarlanmıştır.

Müzenin fotoğraf arşivi taranmış ve İzmit Kağıt Fabrikası'nın

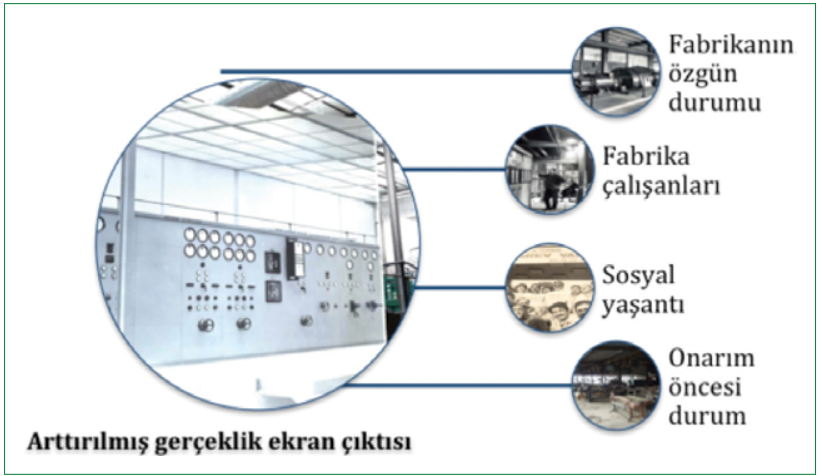

Şekil 7. SEKA Kağıt Müzesi arttııııış gerçeklik tasarımı.

önemli kültürel katmanları belirlenmiştir. Buna göre fabrikanın işlevde olduğu dönem, fabrika işçileri, fabrika yerleşkesinde sosyal yaşantı ve fabrikanın onarım öncesi durumuna ilişkin dört katmanın birlikte kullanılması ile fabrikanın daha bütüncül olarak ziyaretçilere anlatılmasının sağlanacağına karar verilmiştir (Şekil 7).

Müze içinde yapılan değerlendirmeler ile arttırılmış gerçekliğin uygulanacağı mekan ve sergi objeleri belirlenmiştir.

Kullanım amacı göz önünde bulundurularak ara yüz tasarımıyla yüklenecek bir mobil müze uygulaması tasarlamak yerine, cihazların kameraları ile aktif hale gelecek tanıma tabanlı AG uygulamasının yeterli olacağına karar verilmiştir. Bu nedenle artırılmış gerçeklik projesi, Unity oyun motoru (version 2017.2.0f3) ve Vuforia yazılım geliştirme kiti (SDK kütüphanesi) kullanılarak oluşturulmuştur. Unity 3D oyun motoru, birçok farklı formattaki 3D modellerini desteklemesi ve geliştirilen uygulamaların Android platformunda sorusuz şekilde çalışmasına olanak sağlaması ve ücretsiz versiyonunun bulunması nedeniyle tercih edilmiştir.

AG kamerasının, işaretleyici olan hedef görseller üzerinden çalışması ile fabrika içi zamansal farklılıkların çevredeki gerçek ögeler referans alınarak algılanabilmesi hedeflenmiştir. Belirlenen alanların arşiv fotoğrafları, yeniden üretilebilir olmasına dikkat edilerek seçilmiştir. Geçmişteki ve güncel halinin fotoğraflarının görme açılarındaki benzerliğin eşleşmesi konunun doğru bir algı ile aktarımı açısından önemlidir. Bu nedenle seçilen fotoğraflar, Kocaeli Üniversitesi Güzel Sanatlar Fakültesi Fotoğraf Bölümü'nün Mimari Fotoğraf dersi öğrencileri tarafından aynı açıdan yeniden üretilmiştir. Fakat gözetilmesi gereken bir diğer unsur da müzeye gelen ziyaretçilerin gözlemleme noktası ile çekilmiş olan fotoğrafın görme açılarının birbirine örtüşmesidir.

Ziyaretçilerin görme noktasından çekilen fotoğraflar üretilirken dikkat edilen hususlardan biri ışık değerleri yani konunun aydınlanması olmuştur. Konu tripod kullanılarak fotoğraflanmış birbirinden farklı poz değerlerine sahip ışık koşullarında 


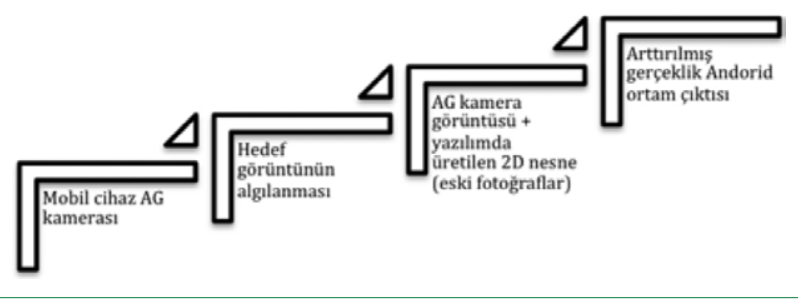

Şekil 8. Artıııılmış gerçeklik uygulamasının çalışma mantığı.

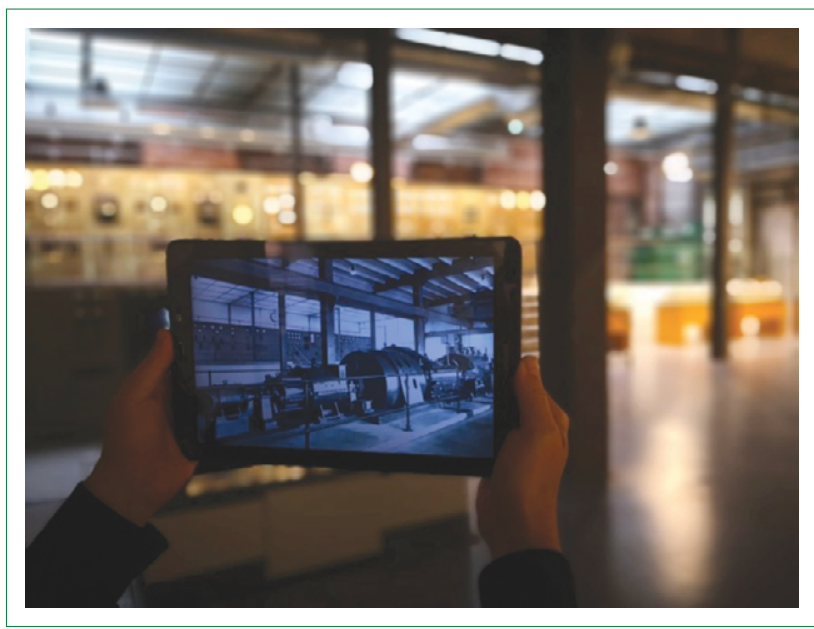

Şekil 9. Fabrika Güç Ünitesi, arttırımış gerçeklik ekran çıktısı.

tekrarlanmıştır. Arttırılmış gerçeklik uygulaması yaptığımız programın gün koşullarına bağlı olarak değişen farklı ışık koşullarının her birinde çalışabilmesi sağlanmıştır.

Sergi objeleri ile ilişkilendirilen arşiv görüntüleri için bakış yönü birincil derecede önem taşımamaktadır.

Çekilen hedef üzerinden gösterilmesi planlanan eski fotoğraflar nesne olarak Unity yazılımına yerleştirilmiştir (Şekil 8).

Müzede yapılan testlerde, AG kamerasının akıllı telefon ya da tablet üzerinden hedef görüntüleri özellikle yapay ışıkta rahatlıkla algıladığı tespit edilmiştir (Şekil 9, I0). Ancak kullanım sırasında, hedef görüntünün algılanabilmesi ve arttırılmış gerçekliğin çalışabilmesi için kullanıcı konumunun kontrol edilmesi gerektiği anlaşılmıştır. Bu nedenle kullanımın yenilenebileceği noktalar grafiksel yönlendirme ile işaretlenmiştir. Kullanıcı konumunun kontrolü için QR kod işaretleyicinin tercih edilmemesinin nedeni eş zamanlı algı bütünlüğünü bozmamak, geçmiş ve gerçek zamandaki aynı perspektifi korumaktır (Şekil 6, 7).

Küme örnekleme yöntemi ile farklı yaş grubundan seçilen 50 ziyaretçinin uygulamanın kullanımın kolaylığı ve kullanım faydasına ilişkin görüşleri, Galaxy Tab A (2016) SM-P580 model tabletler kullanılarak anket yöntemi ile ölçülmüştür. Ziyaretçiler uygulama ile ilgili bilgilendirilmiş ve müzede ilgili noktalar-

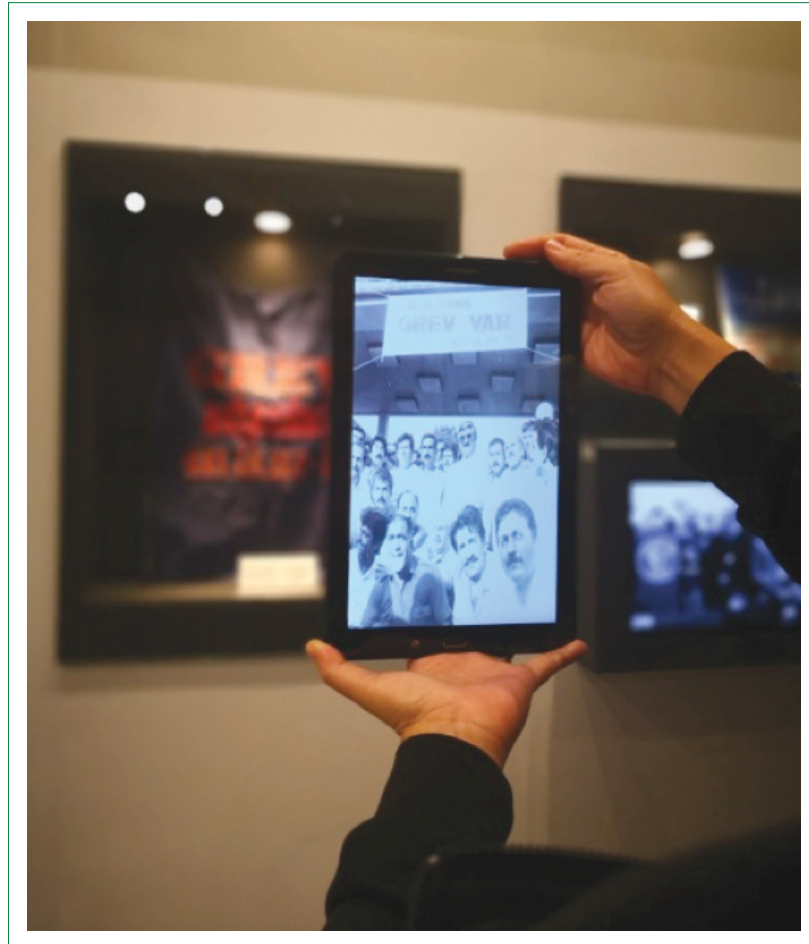

Şekil I0. Sergi alanı, “Grev Gözcüsü” yeleği üzerine yerleştirilen arttııılmış gerçeklik ekran çıktısı.

da uygulamanın kullanılması sağlanmıştır. AG uygulaması turu sonunda ziyaretçilere yaş, cinsiyet, tablet teknolojisine ve arttırılmıs gerçeklik uygulamalarına yatkınlık ile uygulamanın faydasına ilişkin sorular sorulmuştur. Sorular konunun I (kesinlikle katıllmıyorum) ile 5 (kesinlikle katılıyorum) arasında derecelendirilmesi istenmiştir. Frekans dağılımına göre ölçülen anket sonuçları Tablo I'de verilmiştir.

Anket verileri değerlendirildiğinde, katılımcıların tablet kullandıkları ancak AG uygulamalarını tanımadıkları anlaşılmaktadır. Tüm katılımcılar uygulamanın kullanımının çok kolay olduğunu belirtmektedir. Özellikle 30 yaş ve üzeri katılımcılar uygulamayı yararlı bulmuştur. Ancak, ankete katılan bütün ziyaretçiler özellikle uygulamanın mekanla ilişkili noktalarında fabrika binasının eski fotoğraflarını yerinde görmenin çok etkileyici olduğunu belirtmişlerdir. Katılımcılar deneyimlerini "zamanda yolculuk yapmak" ya da "geçmişi üç boyutlu görmek" olarak tarif etmişlerdir. Bazı kullanıcılar fotoğraf dışında akan görüntülerin de kullanılmasını önermişlerdir. Onarım öncesi görüntü ise müzenin dönüştürülmesi projesinin boyutunu ziyaretçilere aktarmada yararlı bulunmuştur.

\section{Sonuç}

Türkiye'nin kozmopolit ve genç kentsel nüfus yapına yönelik kentlerdeki sosyal ve kültürel mekân planlamasında sadece fiziksel müdahalelerin zamanla yetersiz kaldığı anlaşılmaktadır. 
Tablo I. SEKA Kağıt Müzesi AG uygulaması, frekans dağlımına göre ölçülen anket sonuçları

\begin{tabular}{|c|c|c|c|c|}
\hline & \multirow{2}{*}{$\begin{array}{c}\text { Tablet kullanımına } \\
\text { yatkınlık }\end{array}$} & \multirow{2}{*}{$\begin{array}{c}\text { Arttırılmış gerçeklik } \\
\text { uygulamalarına yatkınlık }\end{array}$} & \multicolumn{2}{|c|}{ SEKA Kağıt Müzesi AG uygulaması } \\
\hline & & & Kullanım kolaylığı & Kullanım yararı \\
\hline \multicolumn{5}{|l|}{ Cinsiyet } \\
\hline Kadın $(n=15)$ & 5 & 2 & 5 & 4 \\
\hline Erkek $(n=35)$ & 5 & 3 & 5 & 4 \\
\hline \multicolumn{5}{|l|}{ Yaş } \\
\hline $8-18(n=5)$ & 5 & 4 & 5 & 3 \\
\hline $19-29(n=25)$ & 5 & 3 & 5 & 3 \\
\hline $30-39(n=17)$ & 5 & 2 & 5 & 4 \\
\hline $40-50(n=3)$ & 4 & 2 & 5 & 5 \\
\hline
\end{tabular}

Yeniden işlevlendirilen endüstriyel alanlarda dijital araçların kullanımı, bu mekânların içeriğine katkı yaparak tarihsel geçmişleriyle birlikte anlam kazanmalarını ve yapının kendisinin yaşayan, dönüşen ve sergilenen bir obje olarak algılanmasını sağlamaktadır. Böylelikle, endüstriyel dönüşüm mekânları sanatsal ve tarihsel bağlamda eğitim işlevleri ile birlikte sosyal amaçların ön plana çıktığı kent planı içinde alternatif alanlar haline gelebilir.

SEKA Kağıt Fabrikası'nın çağdaş endüstriyel mirasın korunması anlayışı ve bütüncül bir yaklaşımla müze olarak sergilenmesi için dijital yöntemler kullanılması henüz başlangıç aşamasında olan bir projedir. Dijital yöntemler, mekan büyüklüğü ve somut olmayan kültürel değerlerin yoğunluğu düşünüldüğünde endüstriyel alanların hem korunması ve belgelenmesi hem de ziyaretçilere aktarılması için önemli bir alternatif oluşturmaktadır.

İzmit SEKA Kağıt Müzesi, terk edilen endüstriyel alanların korunmasında bu tür yöntemlerin uygulanması ve geliştirilmesi için yetkin bir örnektir. Erken Cumhuriyet tarihinin gelişmiş sanayi üretim tesislerinden biri olan SEKA Kağıt Fabrikası, teknolojik özellikleri ve ulusal boyutta yaşanan değişimlerin yerel yansımalarının rahatlıkla takip edilebildiği kent belleğindeki konumu ile özgün değer taşımaktadır.

Proje kapsamında yapılan uygulamalar, geleneksel yöntemlerle takip edilmesi zor olan farklı zamansal ve mekânsal katmanların birlikte algılanabilmesini sağlamaktadır. Ayrıca, ziyaretçi profilinin büyük oranda kentte yaşayan ve ortaöğretim seviyesindeki gençlerden oluşması nedeniyle görsel teknolojinin etkileşimli olarak sergilemeye dâhil olması Kağıt Fabrikası mirasının aktarılmasındaki etkiyi ve müzenin kent belleğindeki rolünü arttırmaktadır.

Ziyaretçilerin Bir Kent - Bir Mekan fotoğraf sergisi ve AG uygulaması ile ilgili memnuniyetin değerlendirilmesi ile ileride ya- pılacak çalışmalar şekillendirilecek ve yerel yönetimlerin katkısının bu alana yönelmesi sağlanmaya çalışılacaktır. Böylece, müzeye dönüşen fabrika binasının bağlı olduğu somut olmayan kültürel miras unsurlarının bütüncül bir yaklaşımı ile değerlendirilmesi ve çok yönlü üretim biçimleri ile aktarılmasıyla "SEKA Kağıt Müzesi“" kent belleği ve kültürel aidiyet kavramı çerçevesinde vurgulanmış olacaktır. 


\section{KAYNAKLAR}

Altunbaş, A., \& Özdemir, Ç. (2012). Çağdaş müzecilik anlayışı ve ülkemizde müzeler. Mesleki/Bilimsel Çalışmalar ve Yayınlar, Ankara.

Arkiv, http://www.arkiv.com.tr/proje/seka-kagit-muzesi-ve-kocaeli-bilimmerkezi/7372

Aydın, O., KArtal, R.Ç. (2016). Kocaeli SEKA I. Kağıt Fabrikası́nın Mimarı Analizi ve Yeniden Kullanım Önerileri, TÜBA Kültür Envanteri, 8(8), 21-34.

Bergeron, L. (2012). The heritage of industrial society. Industrial heritage retooled: The TICCIH guide to industrial heritage conservation, 31-37.

Bostanc1, E. (2011). Kültürel miras için zenginleştirilmiş gerçeklik uygulamaları. Pamukkale Üniversitesi Mühendislik Bilimleri Dergisi, 17(3), 133 142.

Cihanger, D. (2012). Endüstri Mirasının Değeri ve Korunma Sorunu: Maltepe Havagazı Fabrikası́nın İzleri Silinirken. Planlama 1-2, 29-36.

Coşkun, C. Bir Sergileme Yöntemi Olarak Artırılmış Gerçeklik. Sanat ve Tasarım Dergisi, (20), 61-75.

Ćopić, S., ĐorđevićA, J., Lukić, T., Stojanović, V., Đukičin, S., Besermenji, S., Tumarić, A. (2014). Transformation of industrial heritage: An example of tourism industry development in the Ruhr area (Germany). Geographica Pannonica, 18(2), 43-50.

Crary, J. (2004). Gözlemcinin Teknikleri. Elif Daldeniz (çev.), Metis Yayınları, İstanbul.

Cakir, H., Yildirim Gonul, B. (2015). Tarihi Yapılarda Mekansal Belleğin Korunması: İzmit SEKA Selüoz ve Kağıt Fabrikasının Dönüşümü, Beykent Üniversitesi Fen ve Mühendislik Bilimleri Dergisi, 8(2), 85-110.

Del Pozo, P.B., Gonzalez, P.A. (2012). Industrial heritage and place identity in Spain: from monuments to landscapes. Geographical Review, 102(4), 446-464.

Erbay, M. (2011). Müzelerde Sergileme ve sunum tekniklerinin planlanması. Beta Basım, İstanbul.

Falconer, K. (2006). The industrial heritage in Britain-the first fifty years. La revue pour l'histoire du CNRS, (14).

Hain, V., Löffler, R., \& Zajíček, V. (2016). Interdisciplinary cooperation in the virtual presentation of industrial heritage development. Procedia engineering, 161, 2030-2035.

Isenberg, A. (2010). "Culture-a-Go-Go": the Ghirardelli Square sculpture controversy and the liberation of civic design in the 1960s. journal of social history, 379-412.

Khan, M., de Byl, P. (2011). Preserving our Past with Toys of the Future. In Ascilite.

Kocabaşoğlu, Uygur vd. (1194) SEKA Tarihi, SEKA Genel Müdürlüğü Yayınları, İzmit.

Dölen, E. (2015) Çinden Kocaeli’ne Kâğıdın Öyküsü, Kocaeli Büyükşehir Belediyesi Yayınları, Kocaeli.

Koyuncu, B., \& Bostanci, E. (2007). Virtual reconstruction of an ancient site: Ephesus. In Proceedings of the XIth symposium on mediterranean archaeology, 233-236.

Landorf, C. (2009). Managing for sustainable tourism: a review of six cultural World Heritage Sites. Journal of Sustainable Tourism, 17(1), 53-70.

Loures, L. (2015). Post-industrial landscapes as drivers for urban redevelopment: Public versus expert perspectives towards the benefits and barriers of the reuse of post-industrial sites in urban areas. Habitat International, $45,72-81$.

Minchinton, W. (1983). World industrial archaeology: a survey. World Archaeology, 15(2), 125-136

Morrison, Tess, Gu, Ning \& Foulcher, Nicholas. (2012). Morrison Tessa, Gu Ning, Foulcher Nicholas Charles, 'Applying augmented reality to preser- ving industrial heritage', Proceedings. EVA London 2012: Electronic Visualisation and the Arts, London, UK (2012).

Oğuz, D., Saygı, H., Akpınar, N. (2010). Kentiçi Endüstri Alanlarının Dönüşümüne Bir Model: İzmit/Sekapark. Coğrafi Bilimler Dergisi, 8(2), 157-167.

Özdemir, N. (2009). Kültür ekonomisi ve endüstrileri ile kültürel miras yönetimi ilişkisi. Milli folklor, 21(84), 73-86.

Özden, E. R. O. L. (2017). Kolektif Bellekteki Değişkenleriyle İzmit’te Kamusal Mekân Algısı. Journal of Architectural, 2(1), 89-103.

Özgüç, N. (1986). Türkiyéde Sanayi Faaliyetlerinin Gelişmesi, Yapısı ve Dağılışı. İstanbul Üniversitesi Edebiyat Fakültesi Coğrafya Bölümü Dergisi, (2), 35-70.

Rodwell, D. (2008). Urban regeneration and the management of change: Liverpool and the historic urban landscape. Journal of Architectural Conservation, 14(2), 83-106.

Saner, M. (2012). Endüstri Mirası: Kavramlar, Kurumlar ve Türkiyédeki Yaklaşımlar, Planlama 1-2, 53-66.

Storm, A., Olsson, K. (2013). The pit: landscape scars as potential cultural tools. International Journal of Heritage Studies, 19(7), 692-708.,

Uzun, M. (2014). Endüstri alanı dönüşüm projesi Sekapark'ın (Kocaeli-İzmit) kıyı kullanımına etkisi, Marmara Coğrafya Dergisi, 30, 154-179.

Yllmaz, H. (2014). Eskişehir' in Biricik Destinasyon Önerisi Endüstriyel Miras. Dokuz Eylül Üniversitesi İktisadi ve İdari Bilimler Fakültesi Dergisi, 29(2), 205-225. 